\title{
Synthesis and Properties of Azaphthalocyanines with 1,2,3,4-Tetrahydropyrazino[2,3-b]pyrazine Moiety
}

\author{
Kamil Kopecky, ${ }^{a}$ Veronika Novakova ${ }_{1}{ }^{\mathrm{b}}$ Miroslav Miletin ${ }^{\mathrm{a}}{ }^{2}$ Lucie Plistilova ${ }^{\mathrm{a}}$ \\ Pavel Berka, ${ }^{\mathrm{c}}$ and Petr Zimcik ${ }^{\mathrm{a}}$
}

Dedicated to Professor Claudio Ercolani on the occasion of his $75^{\text {th }}$ birthday

\author{
${ }^{a}$ Department of Pharmaceutical Chemistry and Drug Control, \\ ${ }^{\mathrm{b}}$ Department of Biophysics and Physical Chemistry, \\ ${ }^{c}$ Department of Pharmaceutical Technology, Faculty of Pharmacy in Hradec Kralove, Charles University in Prague, \\ Heyrovskeho 1203, Hradec Kralove, 50005, Czech Republic \\ ${ }^{\circledR}$ Corresponding author E-mail: petr.zimcik@faf.cuni.cz
}

\begin{abstract}
New metal-free and zinc azaphthalocyanines (AzaPc) containing peripheral tetrahydropyrazino moiety were prepared from 5,8-disubstituted (ethyl, phenyl, benzyl) 5,6,7,8-tetrahydropyrazino-[2,3-b]pyrazine-2,3-dicarbonitriles. All investigated compounds exerted very low singlet oxygen production due to intramolecular charge transfer (ICT). Conjugation of the donor centers (nitrogens of the tetrahydropyrazino moiety) with peripheral aromatic ring (phenyl) decreased partially their ability to undergo ICT, most likely due to decreased electron density on the lone pair of the concerned nitrogens. AzaPc with peripheral benzyl substituents showed interesting aggregation behavior in toluene. Their apparent solutions were shown to be microsuspensions with particles size around $200 \mathrm{~nm}$. These particles caused appearance of the new band at longer wavelengths in region 730-760 nm.
\end{abstract}

Keywords: Tetrapyrazinoporphyrazine, aggregation, singlet oxygen, intramolecular charge transfer.

\section{Introduction}

Phthalocyanines (Pc) and their aza-analogues azaphthalocyanines (AzaPc) attracted attention of researchers for several decades. ${ }^{[1,2]}$ Their large $\pi$-conjugated macrocyclic system is responsible for interesting optical, ${ }^{[3]}$ photochemical, photophysical ${ }^{[4]}$ or redox properties. ${ }^{[5]}$ For this reason they have been systematically investigated as promising compounds in many areas including photodynamic therapy (PDT), ${ }^{[6,7]}$ non-linear optics, ${ }^{[8,9]}$ photovoltaics $^{[10]}$ and electrochemistry. ${ }^{[1]}$ Recently, dialkylamino substituted AzaPc were shown to serve as highly efficient dark quenchers of fluorescence in DNA hybridization probes. ${ }^{[12]}$ This application is connected with ultrafast intramolecular charge transfer (ICT) from peripheral dialkylamino substituents (donors) to AzaPc macrocycle (acceptor). ${ }^{[13]}$ ICT deactivates the excited states and drastically lowers singlet oxygen and fluorescence quantum yields almost to zero. This is, however, a great advantage for quenchers of fluorescence in DNA probes, because highly reactive singlet oxygen could destroy the oligonucleotide probe and native fluorescence of the quencher may interfere with fluorescence of the reporter dye. A deeper understanding of the ICT process and properties of the donor centers is therefore a necessity for future rational design of new dark quenchers.

Photophysical,photochemicalaswellasphysicochemical properties of $\mathrm{Pc}$ and AzaPc are largely influenced by character of the peripheral substituent. Particularly in the case of ICT, electron density on a lone pair of dialkylamino substituent may significantly affect its ability to transfer the electron. This work describes new type of AzaPc derivatives substituted with dialkylamino and alkylarylamino substituents incorporated in tetrahydropyrazino moiety and their unusual aggregation properties. The peripheral substituents were also studied from the point of view of their influence on electron density on the donor center.

\section{Experimental}

All organic solvents used were of analytical grade. Anhydrous butanol was stored over magnesium and distilled prior to use. All chemicals for synthesis were obtained from established suppliers (Aldrich, Acros, Merck, TCI Europe) and used as received. Zinc phthalocyanine $(\mathrm{ZnPc})$ was purchased from Aldrich. TLC was performed on Merck aluminium sheets with silica gel 60 F254. Merck Kieselgel $60(0.040-0.063 \mathrm{~mm})$ was used for column chromatography. CEM Discover and Explorer 24 Automated Microwave Synthesis Workstation with 24-position reaction deck (CEM Corporation, Matthews, North Carolina, USA) was used during synthesis of some compounds. Melting points were measured on Electrothermal IA9200 Series Digital Melting Point apparatus (Electrothermal Engineeering Ltd., Southend-on-Sea, Essex, Great Britain). Infrared spectra were measured on Nicolet 6700 in ATR mode. ${ }^{1} \mathrm{H}$ and ${ }^{13} \mathrm{C}$ NMR spectra were recorded on Varian Mercury Vx BB 300 or VNMR S500 NMR spectrometers. Chemical shifts reported are given relative to $\mathrm{Si}\left(\mathrm{CH}_{3}\right)_{4}$ and were locked to the signal of solvent. The UV-vis spectra were recorded using a Shimadzu UV-2401PC spectrophotometer. The fluorescence spectra were measured on an AMINCO-Bowman 
Series 2 luminescence spectrometer. MALDI-TOF mass spectra were recorded in positive reflectron mode on a Voyager-DE STR mass spectrometer (Applied Biosystems, Framingham, MA, USA) in trans-2-[3-(4-tert-butylphenyl)-2-methyl-2-propenylidene]malononitrile as the matrix. The instrument was calibrated externally with a five-point calibration using Peptide Calibration Mix 1 (LaserBio Labs, Sophia-Antipolis, France). High resolution (HR) mass spectra were obtained using the same instrument but each spot was further calibrated internally after addition of metal-free azaphthalocyanine with peripheral camphorquinone units $^{[14]}$ to the mass of its monomer $\left(\mathrm{m} / z\right.$ 954.5030 $\left.[\mathrm{M}]^{+}\right)$and dimer that appeared in the mass spectrum as well $(\mathrm{m} / \mathrm{z} 1909.0061$ $\left.[2 \mathrm{M}]^{+}\right)$. The photon correlation spectrometer Zetasizer Nano-ZS (Malvern, UK) equipped with red laser $(633 \mathrm{~nm})$ was used for the characterization of the size of the aggregates using dynamic light scattering.

\section{Synthesis}

General procedure for the preparation of tetrahydropyrazinopyrazine-2,3-dicarbonitriles 1-3. 5,6Dichloropyrazine-2,3-dicarbonitrile (199 mg, $1 \mathrm{mmol}$ ) was dissolved in THF $(20 \mathrm{ml})$, corresponding ethan-1,2-diamine (1 $\mathrm{mmol}$ ) was added to solution of potassium carbonate $(138 \mathrm{mg}, 1$ $\mathrm{mmol})$ in water $(1 \mathrm{ml})$ and the water solution was dropped into the THF solution. The mixture was stirred under reflux for 3 hours. Solvent was distilled off under reduced pressure and the solid mixture was suspended in acetone. The suspension was filtered, solvent was removed under reduced pressure and product was recrystallized from methanol. Compound $\mathbf{2}$ was purified by column chromatography on silica (hexane/ethyl acetate $2: 1$ ).

5,8-Diethyl-5,6, 7,8-tetrahydropyrazino-[2,3-b]pyrazine-2,3dicarbonitrile (1). Yield $81 \%$. Mp $195-196^{\circ} \mathrm{C}$ (lit. $196^{\circ} \mathrm{C}^{[15]}$ ). ${ }^{1} \mathrm{H}$ $\operatorname{NMR}\left(\mathrm{CDCl}_{3}, 297 \mathrm{~K}\right) \delta_{\mathrm{H}}$ ppm: $3.65\left(4 \mathrm{H}, \mathrm{q}, J=7 \mathrm{~Hz}, \mathrm{NCH}_{2}\right), 3.57$ $\left(4 \mathrm{H}, \mathrm{s}, \mathrm{NCH}_{2}\right), 1.19\left(6 \mathrm{H}, \mathrm{t}, J=7 \mathrm{~Hz}, \mathrm{CH}_{3}\right) \cdot{ }^{13} \mathrm{C} \mathrm{NMR}\left(\mathrm{CDCl}_{3}, 297 \mathrm{~K}\right)$ $\delta_{\mathrm{C}}$ ppm: $142.5,119.3,115.8,43.8,43.5,11.2$. IR (ATR) $v_{\max } \mathrm{cm}^{-1}: 670$ s, $778 \mathrm{~m}, 921 \mathrm{w}, 957 \mathrm{~m}, 1088 \mathrm{~m}, 1114 \mathrm{~m}, 1282 \mathrm{~s}, 1371 \mathrm{~s}, 1452 \mathrm{~m}$, 1519 s, 1552 s, 1567 s, 2223 m, 2736 w, 2870 w, 2962 w, 2984 w.

5,8-Diphenyl-5, 6, 7,8-tetrahydropyrazino-[2,3-b]pyrazine2,3-dicarbonitrile (2). Yield 58\%. Mp $276-278^{\circ} \mathrm{C}$ (decomp.) (lit. $276^{\circ} \mathrm{C}$ (decomp. $\left.)^{[15]}\right) .{ }^{1} \mathrm{H}$ NMR ([D $\left.] \mathrm{DMSO}, 297 \mathrm{~K}\right) \delta_{\mathrm{H}}$ ppm: 7.467.52 (8H, m, phen.), 7.33(2H, t, $J=7 \mathrm{~Hz}$, phen.), $4.08(4 \mathrm{H}, \mathrm{s}$, $\left.\mathrm{NCH}_{2}\right) \cdot{ }^{13} \mathrm{C}$ NMR $\left(\left[D_{6}\right] \mathrm{DMSO}, 297 \mathrm{~K}\right) \delta_{\mathrm{C}} \mathrm{ppm}: 143.2,142.3,129.4$, 127.0, 125.8, 119.2, 115.7, 47.5. IR (ATR) $v_{\max } \mathrm{cm}^{-1}: 678 \mathrm{w}, 697 \mathrm{~m}$, $764 \mathrm{~m}, 985 \mathrm{w}, 1052 \mathrm{w}, 1141 \mathrm{w}, 1271 \mathrm{w}, 1300 \mathrm{~s}, 1349 \mathrm{~m}, 1379 \mathrm{w}$, 1447 m, 1492 s, 1529 s, 1586 w, 2226 m, 2931 w.

5,8-Dibenzyl-5, 6,7,8-tetrahydropyrazino-[2,3-b]pyrazine2,3-dicarbonitrile (3). Yield $85 \%$. Mp $150-151^{\circ} \mathrm{C}$ (lit. $\left.153^{\circ} \mathrm{C}^{[15]}\right)$. ${ }^{1} \mathrm{H}$ NMR $\left(\mathrm{CDCl}_{3}, 297 \mathrm{~K}\right) \delta_{\mathrm{H}}$ ppm: 7.24-7.36 (10H, m, phen.), $4.83(4 \mathrm{H}$, $\left.\mathrm{s}, \mathrm{NCH}_{2}\right), 3.45\left(4 \mathrm{H}, \mathrm{s}, \mathrm{NCH}_{2}\right) \cdot{ }^{13} \mathrm{C} \mathrm{NMR}\left(\mathrm{CDCl}_{3}, 297 \mathrm{~K}\right) \delta_{\mathrm{C}} \mathrm{ppm}$ : $142.8,135.2,128.9,128.4,128.1,119.6,115.5,51.4,43.4$. IR (ATR) $v_{\max } \mathrm{cm}^{-1}: 674 \mathrm{w}, 694 \mathrm{~s}, 715 \mathrm{~m}, 752 \mathrm{~m}, 855 \mathrm{w}, 1030 \mathrm{w}, 1080 \mathrm{w}, 1255$ m, $1271 \mathrm{~m}, 1300 \mathrm{~m}, 1345 \mathrm{~m}, 1438 \mathrm{~m}, 1456 \mathrm{~m}, 1518 \mathrm{~m}, 1549 \mathrm{~s}, 1588$ w, $2218 \mathrm{~m}, 2878 \mathrm{w}, 2917 \mathrm{w}, 3030 \mathrm{w}, 3065 \mathrm{w}$.

Alternative approach to 5,8-diethyl-5,6,7,8-tetrahydropyrazino-[2,3-b]pyrazine-2,3-dicarbonitrile (1). 5,6-Dichloropyrazine2,3-dicarbonitrile (100 $\mathrm{mg}, 0.5 \mathrm{mmol})$ was dissolved in THF (5 $\mathrm{ml})$ and together with $N^{1}, N^{1}, N^{2}$-triethylethane-1,2-diamine $(0.55$ $\mathrm{ml}, 3 \mathrm{mmol}$ ) was added into a microwave test tube. Upon addition of anhydrous potassium carbonate $(138 \mathrm{mg}, 1 \mathrm{mmol})$ the colorless solution turned a pale yellow. The test tube was placed into a microwave and heated with the following settings: $150^{\circ} \mathrm{C}$ for 10 min, 17 bar and power $200 \mathrm{~W}$. After the reaction was finished, the solvent was evaporated; remains were dissolved in chloroform and water and washed with diluted $\mathrm{NaOH}$. The organic layer was dried $\left(\mathrm{Na}_{2} \mathrm{SO}_{4}\right)$ and evaporated. The product was purified on silica using dichloromethane as eluent to obtain white solid ( $82 \mathrm{mg}, 66$ \%). Mp 193-194 ${ }^{\circ} \mathrm{C} .{ }^{1} \mathrm{H}$ NMR $\left(\mathrm{CDCl}_{3}, 297 \mathrm{~K}\right) \delta_{\mathrm{H}} \mathrm{ppm}: 3.65(4 \mathrm{H}, \mathrm{q}$,
$J=7 \mathrm{~Hz}), 3.57\left(4 \mathrm{H}, \mathrm{s}, \mathrm{CH}_{2}\right), 1.19\left(6 \mathrm{H}, \mathrm{t}, J=7 \mathrm{~Hz}, \mathrm{CH}_{3}\right) .{ }^{13} \mathrm{C} \mathrm{NMR}$ $\left(\mathrm{CDCl}_{3}, 297 \mathrm{~K}\right) \delta_{\mathrm{C}} \mathrm{ppm}: 142.5,119.3,115.8,43.7,43.5,11.2$.

General procedure for the preparation of metal-free AzaPc 5-7. Corresponding tetrahydropyrazinopyrazine-2,3-dicarbonitrile ( $3 \mathrm{mmol}$ ) was dissolved in dry butanol $(15 \mathrm{ml})$, heated to reflux and metal lithium $(21 \mathrm{mmol})$ was added. The mixture turned green immediately and was refluxed for next 3 hours. The solvent was removed under reduced pressure. Diluted acetic acid (50\% (v/v), $100 \mathrm{ml}$ ) was added and the suspension was stirred for 30 minutes. The precipitate was collected and washed thoroughly with water. Dried solid was dissolved in minimal amount of dichloromethane (20-25 ml), dropped into hexane $(250 \mathrm{ml})$, cooled in freezer for 2 hours and filtered. Similar reprecipitation was performed from mixture $\mathrm{DCM} / \mathrm{MeOH}$. Both precipitation procedures were performed twice. Compounds $\mathbf{5}$ and $\mathbf{6}$ were purified further by column chromatography on silica using DCM/MeOH/acetone 10:1:1 and 40:1:1 mixtures, respectively.

Metal-free azaphthalocyanine 5. Yield 52\%. m/z (HR MALDI TOF) 970.5225 (calcd. for $[\mathrm{M}]^{+}$970.5276). ${ }^{1} \mathrm{H}$ NMR $\left(\left[D_{5}\right]\right.$ pyridine, $297 \mathrm{~K}) \delta_{\mathrm{H}}$ ppm: $4.07\left(16 \mathrm{H}, \mathrm{q}, J=7 \mathrm{~Hz}, \mathrm{NCH}_{2}\right), 3.39$ $\left(16 \mathrm{H}, \mathrm{s}, \mathrm{NCH}_{2}\right), 1.25\left(24 \mathrm{H}, \mathrm{t}, J=7 \mathrm{~Hz}, \mathrm{CH}_{3}\right)$. No signals were detected in ${ }^{13} \mathrm{C}$ NMR. IR (ATR) $v_{\max } \mathrm{cm}^{-1}: 654 \mathrm{~m}, 702 \mathrm{w}, 745 \mathrm{~m}$, 965 m 1039 w, 1090 w, 1139 m, 1280 w, 1324 m, 1376 s, 1461 m 1505 s, 1553 m, 1643 w, 2853 w, 2925 w, 3305 w. UV-vis (DMF) $\lambda_{\max } \mathrm{nm}$ (lge): 361 (4.92), 530 (4.85), 642 (4.58), 686 (4.61).

Metal-free azaphthalocyanine 6. Yield 64\%. $\mathrm{m} / \mathrm{z}$ (HR MALDI TOF) 1354.5226 (calcd. for $\left.[\mathrm{M}]^{+} 1354.5276\right) .{ }^{1} \mathrm{H}$ NMR $\left(\left[D_{5}\right]\right.$ pyridine, $\left.297 \mathrm{~K}\right) \delta_{\mathrm{H}} \mathrm{ppm}$ : 7.89-7.99 $(16 \mathrm{H}, \mathrm{m}), 7.69-7.79(16 \mathrm{H}$, $\mathrm{m}), 7.33-7.46(8 \mathrm{H}, \mathrm{m}), 4.06(16 \mathrm{H}, \mathrm{s}) . \delta_{\mathrm{C}}\left(\left[D_{5}\right]\right.$ pyridine, $\left.297 \mathrm{~K}\right)$ overlapped with solvent signals, 144.6, 144.0, 129.6, 129.3, 125.8, 48.0. IR (ATR) $v_{\max } \mathrm{cm}^{-1}: 666 \mathrm{~m}, 692 \mathrm{~m}, 743 \mathrm{~m}, 755 \mathrm{~m}, 989 \mathrm{w}, 1032$ m, $1129 \mathrm{~m}, 1253 \mathrm{~m}, 1299 \mathrm{~m}, 1365 \mathrm{~s}, 1434 \mathrm{~s}, 1476 \mathrm{~s}, 1491 \mathrm{~s}, 1528 \mathrm{~m}$, 2855 w, 2925 w, 3304 w. UV-vis (DMF) $\lambda_{\text {max }} \mathrm{nm}(\lg \varepsilon): 373$ (4.79), 539 (4.64), 686 (4.59).

Metal-free azaphthalocyanine 7. Yield 39\%. m/z (HR MALDI TOF) 1489.6444 (calcd. for $\left.[\mathrm{M}+\mathrm{Na}]^{+} 1489.6426\right) .{ }^{1} \mathrm{H}$ NMR ( $\left[D_{5}\right]$ pyridine, $\left.297 \mathrm{~K}\right) \delta_{\mathrm{H}} \mathrm{ppm}: 7.56-7.67(16 \mathrm{H}$, broad), 7.30$7.41(16 \mathrm{H}$, broad), 7.20-7.30 (8H, broad, overlapped with solvent signal), $5.34\left(16 \mathrm{H}, \mathrm{s}, \mathrm{NCH}_{2}\right), 3.33\left(16 \mathrm{H}, \mathrm{s}, \mathrm{NCH}_{2}\right) . \delta_{\mathrm{C}}\left(\left[D_{5}\right]\right.$ pyridine, $297 \mathrm{~K}$ ) overlapped with solvent signals, 145.6, 139.8, 137.9, 129.3, ,129.0, 127.7, 51.7, 42.9. IR (ATR) $v_{\max } \mathrm{cm}^{-1}: 670 \mathrm{~m}, 701 \mathrm{~s}, 74 \mathrm{~m}, 778$ w, 926 w, 1026 w, 1087 w, 1129 m, 1256 m, 1324 m, 1370 s, 1452 s, $1495 \mathrm{~s}, 1547 \mathrm{~m}, 2860 \mathrm{w}, 3027 \mathrm{w}, 3303 \mathrm{w}$. UV-vis (DMF) $\lambda_{\max } \mathrm{nm}$ (lge): 364 (4.98), 529 (4.89), 645 (4.66), 685 (4.75).

General procedure for the preparation of zinc AzaPc 8-10. Metal-free AzaPc $(0.18 \mathrm{mmol})$ was dissolved in dry DMF (for 9 and 10) or pyridine (for 8) $(20 \mathrm{ml})$, anhydrous zinc acetate $(1.08$ $\mathrm{mmol}$ ) was added and the mixture was refluxed for 2 hours. The mixture was cooled to RT and water $(100 \mathrm{ml})$ was added. The precipitate was collected and washed thoroughly with water. Dried solid was dissolved in minimal amount of dichloromethane (20-25 $\mathrm{ml})$, dropped into hexane $(250 \mathrm{ml})$, cooled in freezer for 2 hours and filtered. Similar reprecipitation was performed from mixture $\mathrm{DCM} / \mathrm{MeOH}$. Both precipitation procedures were performed twice. Compound 9 was further purified by column chromatography on silica using DCM/MeOH/acetone 10:1:1.

Zinc azaphthalocyanine 8 . Yield 57\%. m/z (HR MALDI TOF) 1032.4327 (calcd. for $\left.[\mathrm{M}]^{+} 1032.4411\right) .{ }^{1} \mathrm{H}$ NMR ([ $\left.D_{5}\right]$ pyridine, 297 K) $\delta_{\mathrm{H}}$ ppm: $4.07\left(16 \mathrm{H}, \mathrm{q}, J=7 \mathrm{~Hz}, \mathrm{NCH}_{2}\right), 3.36\left(16 \mathrm{H}, \mathrm{s}, \mathrm{NCH}_{2}\right), 1.24$ $\left(24 \mathrm{H}, \mathrm{t}, J=7 \mathrm{~Hz}, \mathrm{CH}_{3}\right) .{ }^{13} \mathrm{C}$ NMR $\left(\left[D_{5}\right]\right.$ pyridine, $\left.297 \mathrm{~K}\right) \delta_{\mathrm{C}} \mathrm{ppm}$ : 151.5, 144.7, 140.9, 43.9, 43.1, 11.9. IR (ATR) $v_{\max } \mathrm{cm}^{-1}: 660 \mathrm{~m}, 715$ m, $746 \mathrm{~m}, 787 \mathrm{~m}, 966 \mathrm{~m}, 1093 \mathrm{~m}, 1115 \mathrm{~m}, 1211 \mathrm{~m}, 1252 \mathrm{~m}, 1281 \mathrm{~m}$, $1320 \mathrm{~m}, 1371 \mathrm{~s}, 1456 \mathrm{~m}, 1503 \mathrm{~s}, 1562 \mathrm{~m}, 1643 \mathrm{w}, 2868 \mathrm{w}, 2931 \mathrm{w}$. UV-vis (DMF) $\lambda_{\max } \mathrm{nm}$ (lge): 377 (5.03), 531 (4.58), 657 (5.03).

Zinc azaphthalocyanine 9. Yield $62 \% . \mathrm{m} / \mathrm{z}$ (HR MALDI TOF) 1416.4395 (calcd. for $\left.[\mathrm{M}]^{+} 1416.4411\right) .{ }^{1} \mathrm{H}$ NMR $\left(\left[D_{5}\right]\right.$ pyridine, $297 \mathrm{~K}) \delta_{\mathrm{H}}$ ppm: 7.88-7.96 $(16 \mathrm{H}, \mathrm{m}), 7.68-7.77(16 \mathrm{H}, \mathrm{m})$, 7.35-7.54 (8H, m), $4.00\left(16 \mathrm{H}, \mathrm{s}, \mathrm{NCH}_{2}\right) .{ }^{13} \mathrm{C}$ NMR ([D $]$ pyridine, 
$297 \mathrm{~K}) \delta_{\mathrm{C}}$ ppm: $150.8,144.8,143.1,141.8,129.5$ (broad), 129.2, 125.5, 47.9. IR (ATR) $v_{\max } \mathrm{cm}^{-1}: 670 \mathrm{~m}, 694 \mathrm{~s}, 755 \mathrm{~m}, 898 \mathrm{w}, 988 \mathrm{w}$, 1037 m, 1125 m, 1249 m, 1298 m, 1363 s, 1433 s, 1474 s, $1492 \mathrm{~s}$, 1528 w, 1598 w, 2927 w. UV-vis (DMF) $\lambda_{\text {max }} \mathrm{nm}$ (lge): 385 (4.36), 537 (4.27), 603 (4.09), 662 (4.70)

Zinc azaphthalocyanine 10. Yield 95\%. $\mathrm{m} / \mathrm{z}$ (HR MALDI TOF) 1528.5543 (calcd. for $\left.[\mathrm{M}]^{+} 1528.5663\right) .{ }^{1} \mathrm{H}$ NMR $\left(\left[D_{5}\right]\right.$ pyridine, $297 \mathrm{~K}) \delta_{\mathrm{H}}$ ppm: 7.11-7.52 $(40 \mathrm{H}, \mathrm{m}$ broad, overlapped with solvent signal), $4.94\left(16 \mathrm{H}, \mathrm{s}, \mathrm{NCH}_{2}\right), 3.46\left(16 \mathrm{H}, \mathrm{s}, \mathrm{NCH}_{2}\right) .{ }^{13} \mathrm{C}$ NMR ( $\left[D_{5}\right]$ pyridine, $\left.297 \mathrm{~K}\right) \delta_{\mathrm{C}} \mathrm{ppm}: 151.7,144.8,141.3,138.2$, $129.0,128.8,127.4,51.3,44.2$. IR (ATR) $v_{\max } \mathrm{cm}^{-1}: 675 \mathrm{~m}, 700 \mathrm{~m}$, $717 \mathrm{~m}, 745 \mathrm{~m}, 931 \mathrm{~m}, 1011 \mathrm{~m}, 1115 \mathrm{~m}, 1254 \mathrm{~m}, 1323 \mathrm{~m}, 1369 \mathrm{~s}$, $1452 \mathrm{~s}, 1500 \mathrm{~s}, 1547 \mathrm{~m}, 2859 \mathrm{w}, 3028 \mathrm{w}$. UV-vis (DMF) $\lambda_{\max } \mathrm{nm}$ (lge): 379 (4.98), 530 (4.48), 657 (5.09).

\section{Singlet Oxygen Quantum Yields}

Singlet oxygen quantum yields $\left(\Phi_{\Delta}\right)$ of AzaPc were determined according to a previously published procedure using the decomposition of 1,3-diphenylisobenzofuran (DPBF) in DMF. ${ }^{[16]}$ Unsubstituted zinc phthalocyanine $(\mathrm{ZnPc})$ was used as a reference $\left(\Phi_{\Delta}=0.56\right.$ in $\left.\mathrm{DMF}^{[17,18]}\right)$. Absorption of the dyes in the $Q$-band area was set approximately to 0.1 . Presented data represent mean of three measurements.

\section{Results and Discussion}

\section{Synthesis}

5,8-Disubstituted-5,6,7,8-tetrahydropyrazino-[2,3-b] pyrazine-2,3-dicarbonitriles (1-3) may be considered as an analogue of 5,6-bis(diethylamino)pyrazine-2,3dicarbonitrile which was used as a starting material for AzaPc investigated extensively due to interesting properties connected with ICT. ${ }^{[13,19]}$ Moreover, the tetrahydropyrazine ring allows simple influence of electron density on the donor centers (nitrogens in positions 5 and 8) by different substituents (Scheme 1) which makes them highly interesting for photochemical studies. Ethyl, phenyl and benzyl were chosen as an example and compounds 1-3 were synthesized using nucleophilic substitution by corresponding ethane-1,2diamines (Scheme 1) in the presence of $\mathrm{K}_{2} \mathrm{CO}_{3}$. Compounds 1-3 have been already reported ${ }^{[15]}$ but presented procedure gave higher yields without necessity of an excess of the substituted ethane-1,2-diamine.

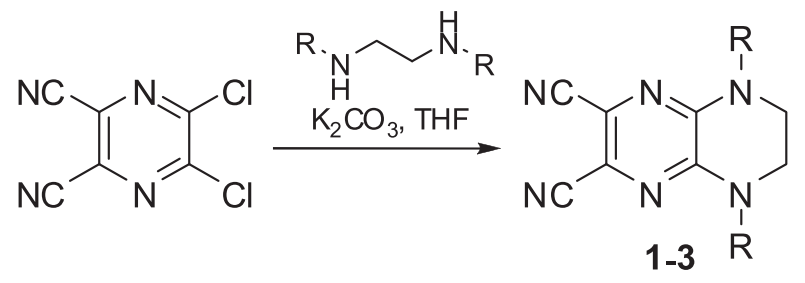

1: $R=$ ethyl
2: $R=$ phenyl
3: $R=$ benzyl $(85 \%)$

Scheme 1.

Peripheral tetrahydropyrazino moiety was obtained also in another reaction that involved unexpected elimination step. In this reaction, compound 4 (Scheme 2) with a peripheral aliphatic tertiary aminosubstituent was intended to be synthesized. Surprisingly, only compound 1 was isolated as a main product $(66 \%)$ from the reaction of 5,6-dichloropyrazine-2,3-dicarbonitrile with an excess of $N^{1}, N^{1}, N^{2}$-triethylethane-1,2-diamine and potassium carbonate in THF using a microwave irradiation (Scheme 2). ${ }^{[20]}$ Only traces of compound $\mathbf{2}$ not worthy of isolation were detected on TLC. The reaction was also performed using different reaction conditions (conventional heating, room temperature, equimolar ratios of starting materials) but the results were always similar. This synthetic pathway was very surprising because nucleophilic substitutions of 5,6dichloropyrazine-2,3-dicarbonitrile with secondary amines are known to proceed well with high yields and a limited number of the side products. ${ }^{[15,21,22]}$ A plausible mechanism of a tetrahydropyrazine ring formation in this reaction involves nucleophilic substitution of one chlorine atom in 5,6-dichloropyrazine-2,3-dicarbonitrile by secondary amine in the first step. Subsequently, a lone pair of the tertiary amine of the attached substituent attacks the second electrondeficient carbon in the pyrazine ring followed by elimination (most likely ethylene) giving rise to compound 1. A proximity effect of the electron rich lone pair of the tertiary amine and stabilization of the final six-membered tetrahydropyrazine ring by elimination seems to push the reaction toward ring closure and limits disubstitution by nucleophilic attack by the second secondary amine. The similar proximity effect was recently reported on formation of the morpholine ring but without any elimination step. ${ }^{[23]}$ When compared to the previous method of synthesis of compound $\mathbf{1}$, this procedure gave lower yields than the one presented on Scheme 1, most likely due to necessity of the final elimination step.

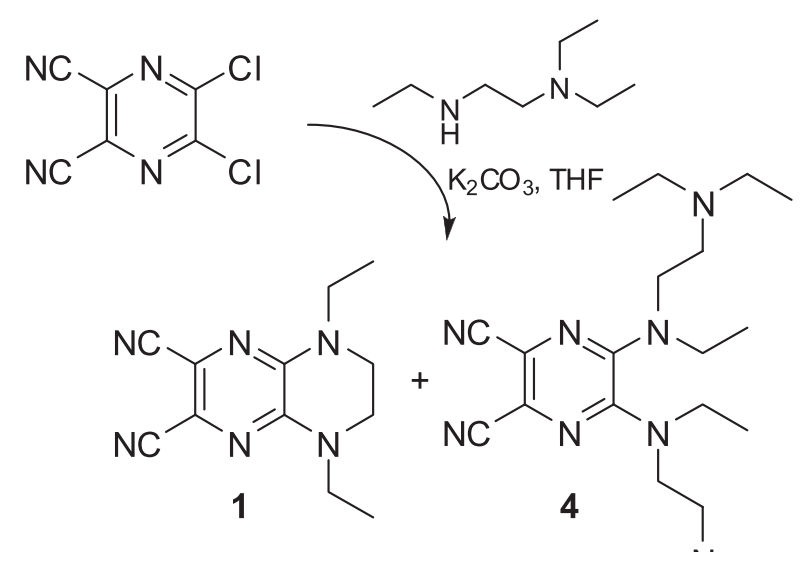

Scheme 2.

Subsequently, metal-free AzaPc 5-7 (Scheme 3) were prepared by cyclotetramerization with lithium butoxide in butanol in $39-62 \%$ yield. Incorporation of zinc(II) into the center of AzaPc core was performed with zinc acetate in DMF under reflux. However, in the case of compound 9, considerable amounts of metal-free form were detected using MALDI-TOF mass spectrometry (MS), although no indications of metal-free residuals were observed on UV-vis spectra. For this reason, incorporation of zinc(II) into the 
center of $\mathbf{6}$ was performed once more, this time in pyridine that gave full transformation according to MS.

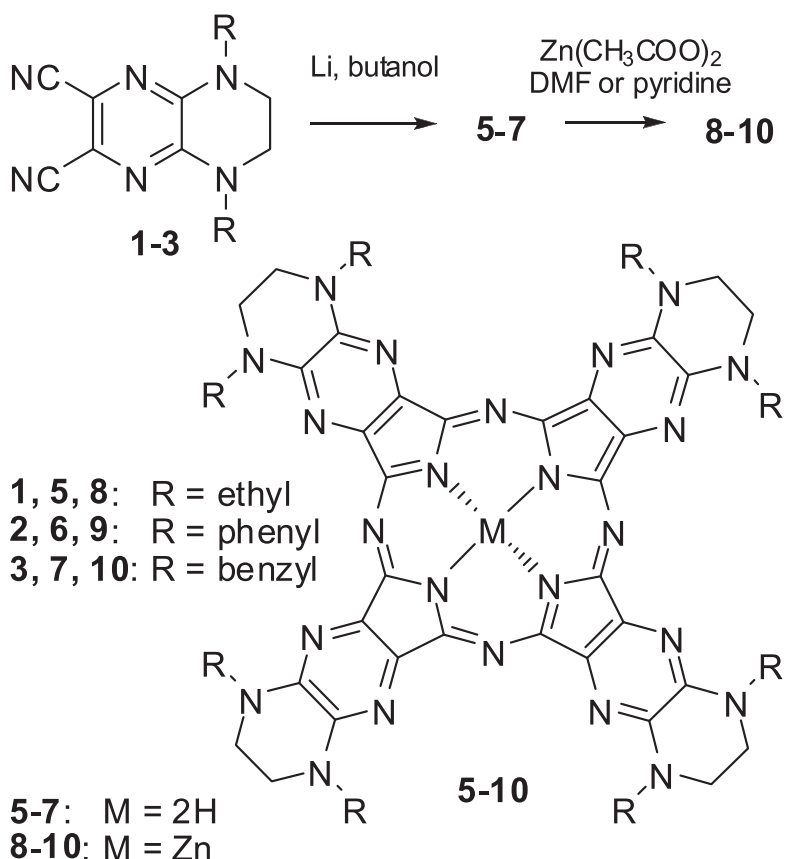

Scheme 3.

Prepared AzaPc were characterized using various spectral methods. They showed good solubility in DMF, DMSO and pyridine, moderate to limited solubility in chloroform, dichloromethane or toluene and were insoluble in methanol or hexane.

\section{Absorption Spectra}

Absorption spectra of AzaPc 5-10 were investigated in different solvents. They showed a typical shape of absorption of monomeric species in DMF (Figure 1) or pyridine with $B$-band in the region $370-380 \mathrm{~nm}$ and $Q$ band in the region 640-680 nm (Table 1). $Q$ band of metal-free 5-7 was split due to a lowered symmetry of the molecule. Besides these bands that are typical for all $\mathrm{Pc}$ and $\mathrm{AzaPc}$, an additional strong band was observed in the region $530-540 \mathrm{~nm}$ due to $\mathrm{n}-\pi^{*}$ transition from the lone pair of the nitrogens in the tetrahydropyrazine moiety that is in conjugation with the macrocyclic system. [13] It is noteworthy, that the spectra of ethyl and benzyl substituted AzaPc (both zinc and metal-free forms) superposed with almost identical shapes of the spectra. On the other hand, all bands of the phenyl substituted derivatives
(6 and 9) were shifted bathochromically when compared with the corresponding ethyl or benzyl derivatives. Interestingly, while position of $Q$ band did not differ too much, positions of $B$ band and $n-\pi^{*}$ transition band were significantly shifted in 6 and 9 (Table 1). Particularly for the latter band it indicates that electron density on the lone pair of the nitrogens in the tetrahydropyrazine moiety is considerably affected by presence of aryl or alkyl substituent. It also suggests a certain level of a communication between the phenyl substituent and the macrocyclic system most likely through the conjugation of the lone pair of the nitrogens in the tetrahydropyrazine moiety.

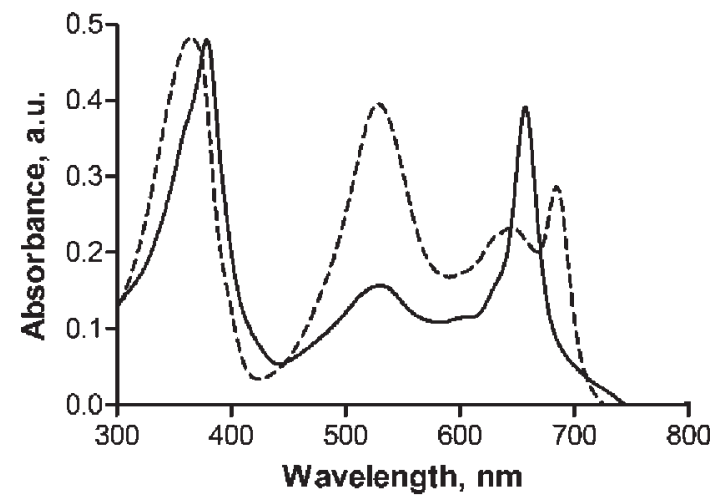

Figure 1. UV-vis absorption spectra of compounds 7 (dashed) and 10 (full) in DMF at concentration $1 \mu \mathrm{M}$.

Although metal-free AzaPc and Pc were reported to form so called "proton-transfer complex" in basic solvents, ${ }^{[23-25]}$ leading to unsplit $Q$ band due to the increased symmetry, no such observations were made for investigated compounds in DMF (Figure 1). Likely explanation may be the low acidity of the central NH in AzaPc macrocycle which is a consequence of a strong electron-donating effect of the peripheral substituents. Similar observations have been reported recently for dialkylamino substituted AzaPc. ${ }^{[26]}$

\section{Aggregation}

Interesting spectra of compounds $\mathbf{7}$ and $\mathbf{1 0}$ were collected in toluene. The other AzaPc did not show any considerable solubility in this solvent. Compounds 7 and 10 were dissolved in toluene with the use of ultrasound (5 min) and gave apparently clear purple or blue solutions, respectively. Their absorption spectra were, however, very broad and a new strongly red-shifted band appeared in the region 730-760 $\mathrm{nm}$ (Figure 2). Broadening of the spectra

Table 1. UV-vis absorption and photochemical data of studied AzaPc in DMF.

\begin{tabular}{cccccc}
\hline Coumpound & $\mathrm{R} / \mathrm{M}$ & $\lambda_{\max }(\lg \varepsilon) B$ band & $\begin{array}{c}\lambda_{\max }(\lg \varepsilon) \mathrm{n}-\pi^{*} \text { transition } \\
\text { band }\end{array}$ & $\lambda_{\max }(\lg \varepsilon) Q$ band & $\Phi_{\Delta}$ \\
\hline $\mathbf{5}$ & ethyl / 2H & $361(4.92)$ & $530(4.85)$ & $686(4.61), 642(4.58)$ & 0.0004 \\
$\mathbf{6}$ & phenyl / 2H & $373(4.79)$ & $539(4.64)$ & $686(4.59)$ & 0.0008 \\
$\mathbf{7}$ & benzyl / 2H & $364(4.98)$ & $529(4.89)$ & $685(4.75), 645(4.66)$ & 0.0004 \\
$\mathbf{8}$ & ethyl / Zn & $377(5.03)$ & $531(4.58)$ & $657(5.03)$ & 0.004 \\
$\mathbf{9}$ & phenyl / Zn & $385(4.36)$ & $537(4.27)$ & $662(4.70)$ & 0.013 \\
$\mathbf{1 0}$ & benzyl / Zn & $379(4.98)$ & $530(4.48)$ & $657(5.09)$ & 0.005 \\
\hline
\end{tabular}


with new bands at longer wavelengths indicates usually presence of $J$-dimers. ${ }^{[27]}$ These were even described and characterized for structurally similar octakis(diethylamino)azaphthalocyanine but only for zinc complex and the red-shift was not so strong $\left(\lambda_{\max }=700 \mathrm{~nm}\right) \cdot{ }^{[19]}$ The reported $J$-dimers were based on a coordination bond between the peripheral diethylamino substituent and central zinc, i.e. they cannot occur at metal-free derivatives (e.g. 7).

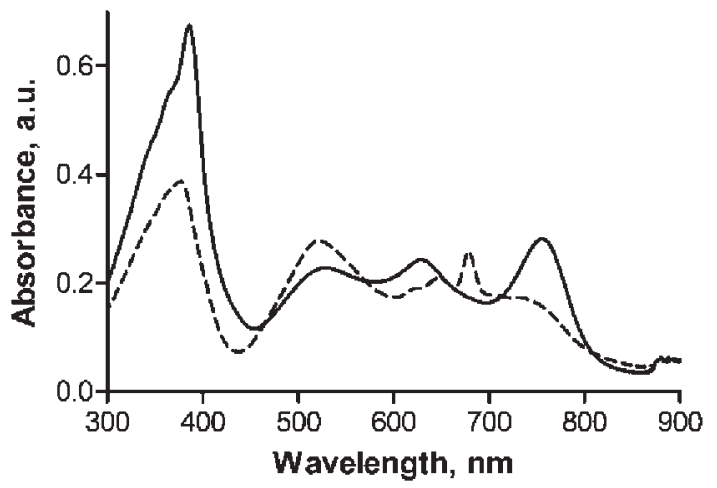

Figure 2. UV-vis absorption spectra of compounds 7 (dashed) and $\mathbf{1 0}$ (full) in toluene at concentration $10 \mu \mathrm{M}$.

Several other findings indicated that the new redshifted bands in the spectra of $\mathbf{7}$ and $\mathbf{1 0}$ did not arise from $J$-dimer formation. Titration of the toluene solution of $\mathbf{1 0}$ with pyridine led to the decrease of the band at $756 \mathrm{~nm}$ with concomitant increase of the $Q$ band of the monomeric species at $656 \mathrm{~nm}$ (Figure 3) but without any apparent isosbestic points. Furthermore, absorption at all wavelengths below 680 $\mathrm{nm}$ increased, including generally very low sensitive $B$ band, suggesting that some undissolved parts finished dissolution. Approximately one order of magnitude lower extinction coefficients in toluene than in DMF led also to the conclusion that some particles were not fully dissolved. We supposed that compounds $\mathbf{7}$ and $\mathbf{1 0}$ in toluene are not (or not fully) dissolved and form a microsuspension. In order to confirm this presumption, the "solutions" were filtered through a fine filter paper and then once more through a teflon filter with $0.22 \mu \mathrm{m}$ pores. A lot of purple or blue material was observed on both filters, the solutions became almost colorless and absorbance of the solutions drastically decreased (Figure 4).

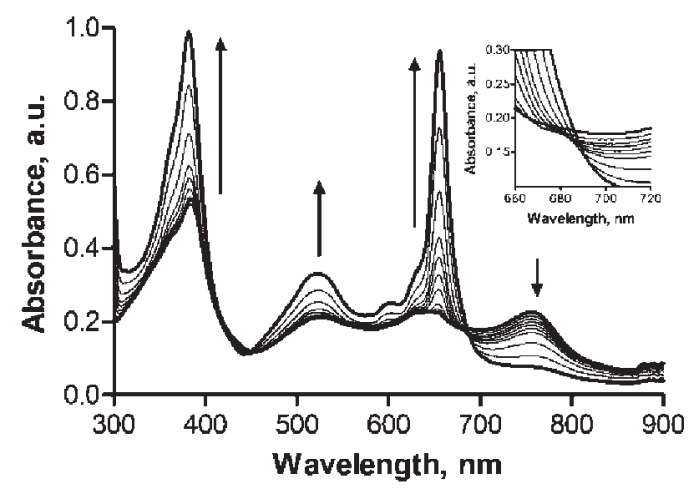

Figure 3. Spectral changes of $\mathbf{1 0}$ in toluene after addition of pyridine (from $0 \%$ to $10 \%(\mathrm{v} / \mathrm{v})$ ). Spectra were corrected for dilution. Inset: enlarged region around $690 \mathrm{~nm}$ indicating no exact isosbestic point.

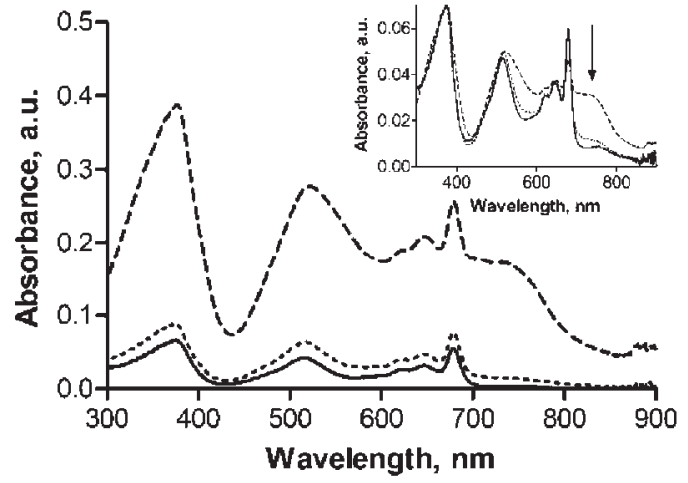

Figure 4. UV-vis absorption spectra of compound 7 in toluene at concentration $10 \mu \mathrm{M}$ after dissolution using ultrasound (dashed). The same solution after filtration through fine filter paper (dotted) and through teflon filter with $0.22 \mu \mathrm{m}$ pores (full). Inset: the same spectra but normalized to the same absorption at $B$ band.

In addition, the toluene solutions of $\mathbf{7}$ and $\mathbf{1 0}$ were investigated with dynamic light scattering (DLS). In case of the unfiltered solutions or the solutions filtered through the filter paper, particles of approximate size $200 \mathrm{~nm}$ with broad range of size (polydispersity index 0.3-0.7) were detected. No or very few particles were detected in the solutions filtered through the $0.22 \mu \mathrm{m}$ teflon filter. In case of 7 , the band at $736 \mathrm{~nm}$ decreased after filtration through filter paper and almost disappeared after filtration through the $0.22 \mu \mathrm{m}$ teflon filter (Figure 4, inset). The shape of the spectrum after filtration through the $0.22 \mu \mathrm{m}$ filter gained a typical monomeric character (compare with Figure 1) suggesting that a cause of the new band was mostly "filtered out". All these measurements indicated that the apparent solutions of $\mathbf{7}$ and $\mathbf{1 0}$ in toluene were actually formed mainly by the microsuspension and that the new band at longer wavelengths was most likely due to the presence of the higher aggregates forming very small particles.

\section{Singlet Oxygen Production}

Both metal-free and zinc AzaPc 5-10 were characterized from the point of view of photochemical properties. All measurements were performed in dilute DMF solutions (absorbance in $Q$ band maximum always below 0.1 ) in monomeric form as deduced from the shape of the absorption spectra. Extremely low singlet oxygen quantum yields $\left(\Phi_{\Delta}\right)$ were detected (Table 1) using decomposition of DPBF, a specific singlet oxygen scavenger. As mentioned above, all parameters were determined in monomeric forms and that is why the aggregation cannot account for such low values. Both these parameters were low due to competitive ICT that deactivated the excited states as reported for similar compounds before. ${ }^{[13]}$ A lack of any significant singlet oxygen production even in monomeric form can be considered as advantage in design of new dark quenchers in DNA hybridization probes, because singlet oxygen produced by photosensitizers is known to destroy oligonucleotides. ${ }^{[28]}$

Some structure-activity relationships can be derived from the obtained data despite lowsinglet oxygen production. The $\Phi_{\Delta}$ values of zinc complexes, although still very low, exceeded those of metal-free derivatives in one order of magnitude. Zinc complexes of AzaPc or Pc are generally 
known to produce strongly singlet oxygen due to longer triplet state lifetimes. ${ }^{[4]}$ Interestingly, the $\Phi_{\Delta}$ values of AzaPc substituted with ethyl or benzyl were comparable (in case of corresponding metal-free or zinc complexes) while those substituted with phenyl were found approximately twice higher. We suppose that the conjugation of the lone pair on the amine with aromatic substituent (phenyl) decreased the electron density on the donor center and thus its ability to undergo ICT. In the case of ethyl or benzyl substitution the conjugation is not present and the compounds behave similarly, allowing very strong ICT. It is in good agreement with conclusions made after analysis of UV-vis absorption spectra (see above).

\section{Conclusions}

In conclusion, new metal-free and zinc AzaPc containing the tetrahydropyrazine moiety were prepared. Investigation on their spectral and photochemical properties indicated some level of communication between peripheral aromatic ring and macrocyclic system in case of phenyl substitution of the tetrahydropyrazine moiety. All investigated compounds exerted very low singlet oxygen quantum yields due to ICT. Conjugation of the donor centers (nitrogens of the tetrahydropyrazine moiety) with the peripheral aromatic ring (phenyl) decreased their ability to undergo ICT, most likely due to the decreased electron density on the lone pair of the concerned nitrogen. AzaPc with peripheral benzyl substituents showed interesting aggregation behavior in toluene. Their apparent solutions were shown to be the microsuspensions with the particles size around $200 \mathrm{~nm}$. The particles caused the appearance of the new band at longer wavelengths in the region $730-760 \mathrm{~nm}$ that disappeared after filtration.

Acknowledgements. The work was supported by Czech Science Foundation, grant No. P207/11/1200 and Ministry of Education, Youth and Sports of the Czech Republic, research project MSM0021620822. Authors would like to thank to Jiří Kuneš for NMR measurements and to Vojtěch Tambor for MS measurements.

\section{References}

1. The Porphyrin Handbook (Kadish K.M., Smith K.M., Guilard R., Eds.). Amsterdam: Academic Press, 1999, Vols. 1-20.

2. Handbook of Porphyrin Science (Kadish K.M., Smith K.M., Guilard R., Eds.). Singapore: World Scientific Publishing, 2010, Vols. 1-10.

3. Mørkved E.H., Afseth N.K., Zimcik P. J. Porphyrins Phthalocyanines 2007, 11, 130-138.
4. Nyokong T., Antunes E. Photochemical and Photophysical Properties of Metallophthalocyanines. In: Handbook of Porphyrin Science (Kadish K.M., Smith K.M., Guilard R., Eds.) Singapore: World Scientific Publishing, 2010, Vol. 7, pp. 247-358.

5. Donzello M.P., Ou Z., Monacelli F., Ricciardi G., Rizzoli C., Ercolani C., Kadish K.M. Inorg. Chem. 2004, 43, 8626-8636.

6. Zimcik P., Miletin M., Radilova H., Novakova V., Kopecky K., Svec J., Rudolf E. Photochem. Photobiol. 2010, 86, 168-175.

7. Lo P.C., Huang J.D., Cheng D.Y.Y., Chan E.Y.M., Fong W.P., Ko W.H., Ng D.K.P. Chem. Eur. J. 2004, 10, 4831-4838.

8. Donzello M.P., Ou Z., Dini D., Meneghetti M., Ercolani C., Kadish K.M. Inorg. Chem. 2004, 43, 8637-8648.

9. Dini D., Hanack M., Meneghetti M. J. Phys. Chem. B 2005, 109, 12691-12696.

10. Martinez-Diaz M.V., de la Torre G., Torres T. Chem. Commun. 2010, 46, 7090-7108.

11. Li N., Zhu M.F., Qu M.L., Gao X., Li X.W., Zhang W.D., Zhang J.Q., Ye J.S. J. Electroanal. Chem. 2011, 651, 12-18.

12. Kopecky K., Novakova V., Miletin M., Kucera R., Zimcik P. Bioconjugate Chem. 2010, 21, 1872-1879.

13. Novakova V., Zimcik P., Miletin M., Vachova L., Kopecky K., Lang K., Chábera P., Polívka T. Phys. Chem. Chem. Phys. 2010, 12, 2555-2563.

14. Jang C.K., Byun S.H., Kim S.H., Lee D.K., Jaung J.Y. J. Porphyrins Phthalocyanines 2009, 13, 794-797.

15. Ried W., Tsiotis G. Liebigs Ann. Chem. 1988, 1197-1199.

16. Musil Z., Zimcik P., Miletin M., Kopecky K., Link M., Petrik P., Schwarz J. J. Porphyrins Phthalocyanines 2006, 10, 122131.

17. Michelsen U., Kliesch H., Schnurpfeil G., Sobbi A.K., Woehrle D. Photochem. Photobiol. 1996, 64, 694-701.

18. Zimcik P., Miletin M., Musil Z., Kopecky K., Kubza L., Brault D. J. Photochem. Photobiol. A 2006, 183, 59-69.

19. Novakova V., Zimcik P., Kopecky K., Miletin M., Kuneš J., Lang K. Eur. J. Org. Chem. 2008, 3260-3263.

20. Subara L. Synthesis of Model Water-Soluble Azaphthalocyanine Fluorescence Quencher. Diploma thesis. Charles University in Prague, Faculty of Pharmacy in Hradec Kralove, Hradec Kralove, 2010.

21. Mørkved E.H., Kjøsen H., Ossletten H., Erchak N. J. Porphyrins Phthalocyanines 1999, 3, 417-423.

22. Zimcik P., Miletin M., Ponec J., Kostka M., Fiedler Z. J. Photochem. Photobiol. A 2003, 155, 127-131.

23. Kopecky K., Zimcik P., Novakova V., Miletin M., Musil Z., Stribna J. Dyes Pigment. 2008, 78, 231-238.

24. Petrik P., Zimcik P., Kopecky K., Musil Z., Miletin M., Loukotova V. J. Porphyrins Phthalocyanines 2007, 11, 487495.

25. Stuzhin P.A. J. Porphyrins Phthalocyanines 1999, 3, 500-513.

26. Kopecky K., Šatinský D., Novakova V., Miletin M., Svoboda A., Zimcik P. Dyes Pigment. 2011, 91, 112-119.

27. Kameyama K., Morisue M., Satake A., Kobuke Y. Angew. Chem., Int. Ed. 2005, 44, 4763-4766.

28. Boutorine A.S., Brault D., Takasugi M., Delgado O., Helene C. J. Am. Chem. Soc. 1996, 118, 9469-9476. 